\title{
Evaluation of Results of Combined Blocking Screw and Interlocking Intramedullary Nail in the Treatment of Diaphyseo-Metaphyseal Tibial Fractures
}

\author{
MOHAMED M. NAGLA, M.Sc.; ALI M. EMRAN, M.D.; ABD EL-HAFEZ A. MEGAHED, M.D. and \\ MAMDOUH F. LASHIN, M.D.
}

The Department of Orthopedic Surgery, Faculty of Medicine, Tanta University, Egypt

\begin{abstract}
Background: Diaphyseo-metaphyseal tibial fractures tend to malalign while treatment by interlocking intramedullary nail. Multiple techniques are used to avoid malalignment as provisional unicortical plate, percutaneous clamping, universal distractor, fibular plating in distal tibia and blocking screw.

Aim of Study: Was to evaluate the results of combined blocking screw and interlocking intramedullary nail in the treatment of diaphyseo-metaphyseal tibial fractures.

Patients and Methods: This study was done on 21 patients with closed proximal or distal diaphyseo-metaphyseal tibial fractures, admitted at Tanta University Hospital. The distribution of patients was according to age, sex, and side, mode of trauma, and AO type of fracture, medical history, smoking, fracture level, time lag, fibular fixation and design of interlocking nail. Fixation was done by interlocking intramedullary nail and the reduction was assisted by blocking screw in the coronal plane for varus or valgus malalignment and in the sagittal plane for recurvatum or procurvatum malalignment. Clinical evaluation was according to Hospital of Special Surgery Knee Rating Scale.
\end{abstract}

Results: There were significant statistical correlation between the final clinical result and interlocking nail design either conventional or expert tibial nail or the time for union. There were significant statistical correlation between the time of union and sex of patients, mode of trauma, type of fracture, fibular fracture fixation and smoking.

Conclusion: Blocking screw is a simple technique that assist in the reduction of diaphyseo-metaphyseal tibial fractures while fixation by interlocking nail, maintenance of the reduction and stability of the fracture.

Correspondence to: Dr. Mohamed M. Nagla, The Department of Orthopedic Surgery, Faculty of Medicine, Tanta University, Egypt
Key Words: Blocking screw - Diaphyseo-metaphyseal tibial fracture-Malalignment.

\section{Introduction}

IT is known fact that proximal and distal fractures of tibia tend to malalign when treated with intramedullary nails or functional braces. Intramedullary nailing for metaphyseal tibia fractures with short proximal and distal fragment is associated with frontal and sagittal plane malalignment. This may be attributed to an inaccurate entry site, displacing muscular forces and residual deformity along with discrepancy between voluminous area of the metaphyseo-diaphyseal junction and size of nail $[\mathbf{1 , 2}]$.

The typical deformity present is valgus and apex anterior (procurvatum) in proximal fractures. The valgus is typically created by using too medial starting point that creates an initial reaming pathway which runs from too medial to lateral [1]. Once the nail is placed, this tips the fracture into valgus. Similarly, the apex anterior deformity is created by the pull of the extensor mechanism and is worsened by an initial reaming path that is angled too far posterior which produces the deformity once the nail is introduced [1].

Several reports describe techniques to overcome this tendency to mal reduce proximal tibia fractures with a nail and have demonstrated relatively low mal reduction rates $[\mathbf{3 , 4}]$.

The use of an ideal starting point and starting wire direction is particularly important for proximal 
fractures for reducing the fracture before reaming. Other techniques to prevent mal reduction include the use of percutaneous clamps. Provisional plating with unicortical screws has also been described. The use of a femoral distractor or an external fixator can be helpful to hold the fracture in a reduced position while nailing [5]. Blocking or "Poller" screws are a particularly useful technique to help guide the nail correctly $[6,7]$.

For distal fractures, are also prone to mal alignment because the metaphysis is much wider than the diameter of the nail and care must be taken to avoid mal union as this may lead to a worse functional outcome $[\mathbf{8 , 9}]$.

The techniques described in the section on proximal fracture mal alignment, including percutaneous clamps, temporary external fixator placement, and blocking screws, can also be very useful for distal fracture pattern [9], plating of the fibula fracture before nailing of the tibia can help provide alignment and length $[9,10]$

\section{Patients and Methods}

This study is retrospective and prospective and carried out on 21 patients complaining of closed Diaphysio-Metaphyseal tibial fractures, admitted at Orthopedic Department of Tanta University Hospital from the period of July 2017 till January 2018 and is followed-up for at least 6 months.

A written informed consent was obtained from every patient, in case of any unexpected risks appearing during the course of the research. This will be cleared to the participants and to the ethical committee in time. Privacy of participants and confidentiality of the data will be given the most care and attention. Each patient data file, including investigations will be code-assigned and only the code will be used in data management without disclosure of patient's name or personal information.

Inclusion criteria included patients above the age of 18, patients fit for surgery and closed Diaphysio-Metaphyseal fracture tibia in less than 14 days. Exclusion criteria were: Patients under 18 years old, patients unfit for surgery, patients unable to weight bear prior to fracture, old trauma more than 14 days, patients with diaphyseal, metaphyseal $\&$ intra articular fracture tibia, open fractures and pathological fracture other than osteoporosis.

All the patients were subjected to the following: Full history taking including mode and time of trauma clinical examination: General examination, musculoskeletal examination, local examination: Including neurovascular examination and soft tissue condition assessment.

Investigations: (1) Laboratory investigations: Full lab (2) Radiological investigations: Plain Xray: (AP and lateral views including knee and ankle joints) \& measurement of length of proximal \& distal metaphyseal fragments. Proximal fragment for proximal fractures was more than $6 \mathrm{~cm}$ and distal fragment for distal fractures was more than $4 \mathrm{~cm}$. CT scan: Of knee and ankle if there was suspicion of intra articular fracture extension.

Surgical technique: Patients were lying supine, medial parapatellar approach for distal fractures and lateral parapatellar for proximal fractures, accurate entry point for the nail which was just medial to lateral tibial spine using fluoroscopy. When the malalignment occurred with presence of the nail, it should be removed, screw placement, guide wire placement in central position then rereaming and nail placement. Coronal plane malalignment (varus and valgus) was prevented by blocking screw from anterior to posterior while sagittal plane malalignment (recurvatum and procurvatum) was prevented by blocking screw from medial to lateral. It was placed in the concave side of deformity in the wide metaphyseal segment or by drawing a line along axis of tibia and another line along the fracture line then the blocking screw was placed in the acute angle at the wide voluminous metaphyseal segment. If the screw caused excessive diversion of the nail, it would be corrected by nail removal, disengagement of the screw from the posterior cortex and passing the nail again. Locking the nail was done by 2 screws proximal and distal to the fracture as in conventional nail or by multidirectional locking screws as in expert tibial nail. Closure was done in layers.

Evaluation of results was clinically using Hospital of special surgery knee rating scale and radiological assessment of union by callus formation in at least three of four cortices and assessment of alignment by X-ray on whole leg. Varus and procurvatum angulations are expressed as positive values, and valgus and recurvatum as negative values.

Statistical presentation \& analysis of present study was conducted using the mean value \& chisquare test by SPSS V. 16. $p$-value $\leq 0.05$ Significant, $p$-value $>0.05$ not significant, $p$-value $<0.01$ highly significant. 


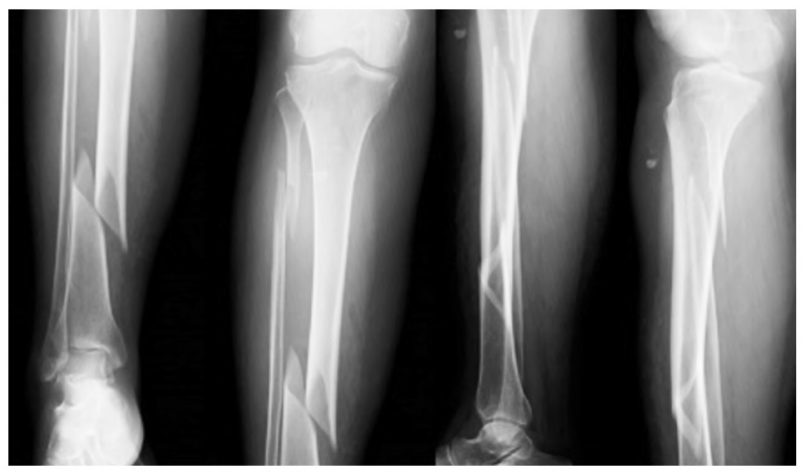

(A)

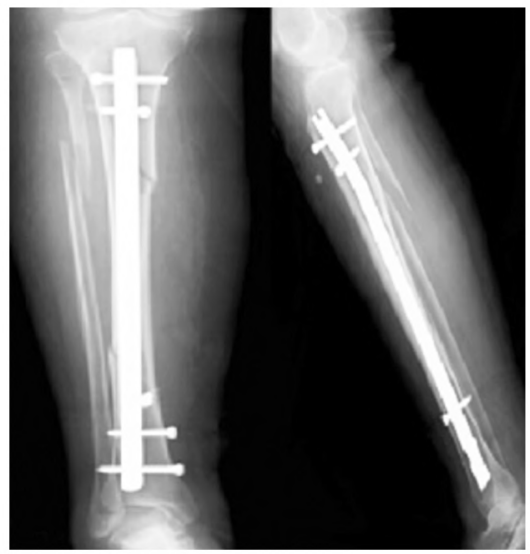

(C)

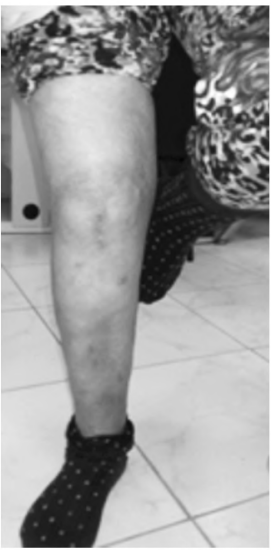

(D)

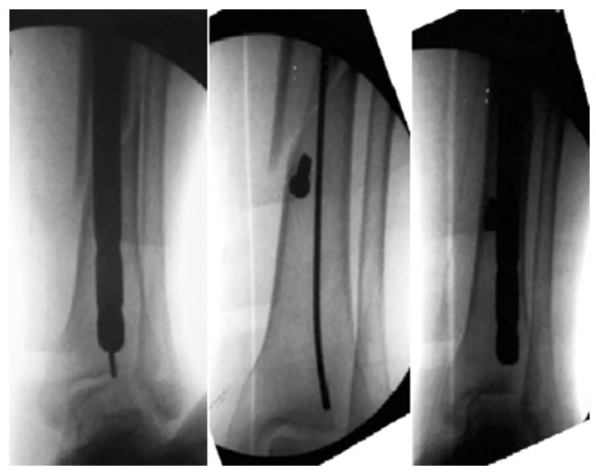

(B)

Fig. (1): (A) AP and lateral views fracture distal BBL, (B) Fluoroscopic views, (C) Post-operative X-ray AP and lateral views, (D) Clinical union as shown by painless weight bearing.

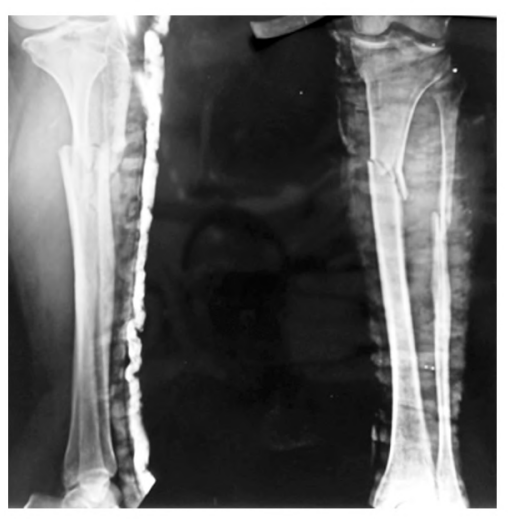

(A)

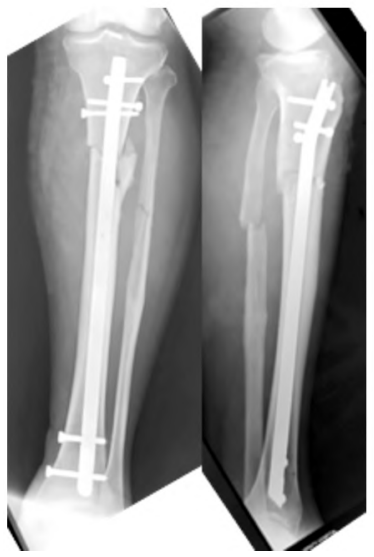

(C)

(D)

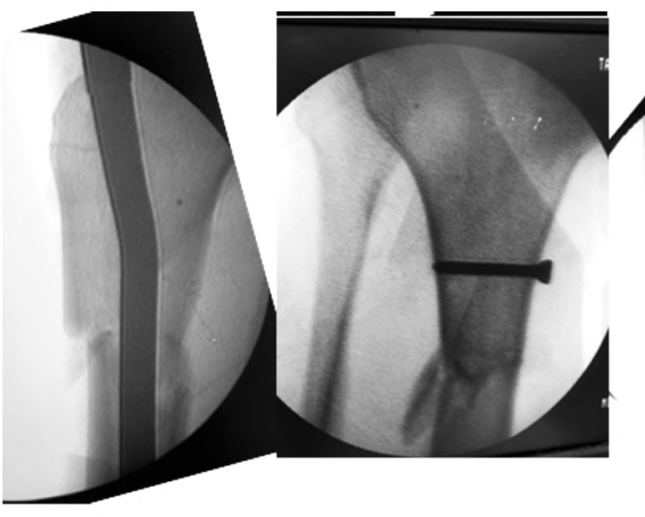

(B)


Fig. (2): AP and lateral X-ray views leg with fracture proximal BBL, (B) Fluoroscopic intraoperative views, (C) Immediate postoperative AP and lateral X-ray views leg, (D) clinical union by painless weight bearing. 


\section{Results}

The final clinical results were excellent in 7 (33\%), good in 11 (53\%) and fair in 3 cases (14\%). The time of union ranged from 16 to 48 weeks with a mean of 24.5 weeks. Malalignment occurred in 2 cases, the first case with fracture proximal tibia developed varus (+10 degrees) and recurvatum (5 degrees) and the other case with fracture distal tibia developed valgus malalignment (7 degrees). Mean varus and valgus malalignment was 0.81 degree while mean recurvatum and procurvatum malalignment was 0.23 degree. Interlocking nail design and time of union was statistically significant with the clinical result. Mode of trauma, type of fracture, smoking and sex of patients were statistically significant with the time of union.

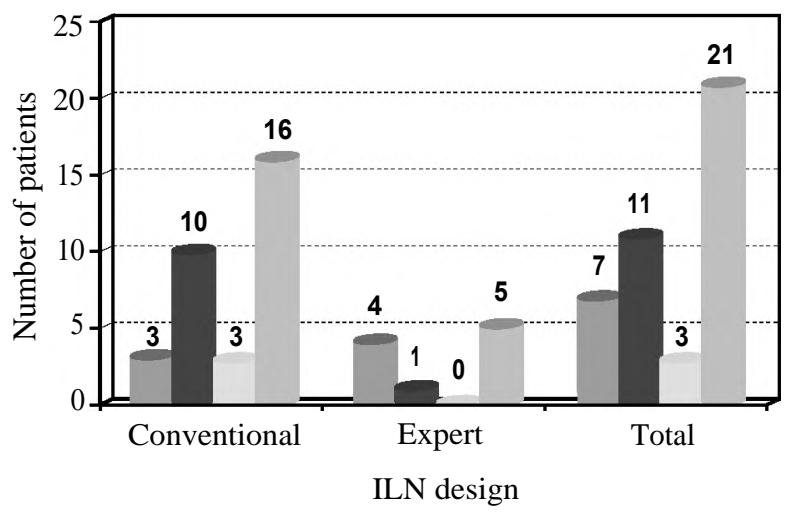
Excellent
Good
Fair
Total

Fig. (3): Relationship of interlocking nail design and final clinical result.

Table (1): Factors affecting the final clinical result and the time of union, $p$-value for each factor and if it is significant or not.

\begin{tabular}{|c|c|c|c|c|c|c|c|}
\hline & \multicolumn{3}{|c|}{ Final clinical result } & \multicolumn{2}{|c|}{ Time of union } & \multirow{2}{*}{$\begin{array}{c}p \text {-value } \\
\text { for } \\
\text { clinical result }\end{array}$} & \multirow{2}{*}{$\begin{array}{c}p \text {-value } \\
\text { for } \\
\text { time of union }\end{array}$} \\
\hline & Excellent & Good & Fair & Ł24 weeks & $>24$ weeks & & \\
\hline \multicolumn{8}{|l|}{ Age: } \\
\hline $20-40$ & 3 & 4 & 3 & 5 & 5 & \multirow[t]{3}{*}{0.36} & \multirow[t]{3}{*}{0.13} \\
\hline$>40-60$ & 0 & 4 & 2 & 3 & 3 & & \\
\hline$>60$ & 2 & 3 & 0 & 5 & 0 & & \\
\hline \multicolumn{8}{|l|}{ Sex: } \\
\hline Male & 4 & 7 & 2 & 8 & 0 & \multirow[t]{2}{*}{0.95} & \multirow[t]{2}{*}{0.005} \\
\hline Female & 3 & 4 & 1 & 5 & 8 & & \\
\hline \multicolumn{8}{|l|}{ Mode of trauma: } \\
\hline MVA & 3 & 6 & 2 & 3 & 1 & \multirow[t]{3}{*}{0.73} & \multirow[t]{3}{*}{0.03} \\
\hline FFH & 1 & 2 & 1 & 4 & 7 & & \\
\hline Twisting trauma & 3 & 3 & 0 & 6 & 0 & & \\
\hline \multicolumn{8}{|l|}{ Medical history: } \\
\hline Present & 3 & 4 & 0 & 7 & 3 & \multirow[t]{2}{*}{0.4} & \multirow[t]{2}{*}{0.466} \\
\hline Absent & 4 & 7 & 3 & 6 & 5 & & \\
\hline \multicolumn{8}{|l|}{ Smoking: } \\
\hline Smoker & 2 & 3 & 2 & 6 & 2 & \multirow[t]{2}{*}{0.42} & \multirow[t]{2}{*}{0.01} \\
\hline Non-smoker & 5 & 8 & 1 & 2 & 11 & & \\
\hline \multicolumn{8}{|l|}{ Fibular fixation: } \\
\hline Fixed & 0 & 3 & 1 & 3 & 0 & \multirow[t]{2}{*}{0.283} & \multirow[t]{2}{*}{0.031} \\
\hline Not fixed & 7 & 8 & 2 & 6 & 12 & & \\
\hline \multicolumn{8}{|l|}{ Type of fracture: } \\
\hline A1 & 6 & 3 & 1 & 0 & 10 & \multirow[t]{4}{*}{0.31} & \multirow[t]{4}{*}{0.002} \\
\hline A2 & 1 & 3 & 1 & 2 & 3 & & \\
\hline B1 & 0 & 1 & 0 & 1 & 0 & & \\
\hline B2 & 0 & 4 & 1 & 5 & 0 & & \\
\hline \multicolumn{8}{|l|}{ ILN design: } \\
\hline Conventional & 3 & 10 & 3 & 7 & 9 & 0.04 & 0.34 \\
\hline Expert & 4 & 1 & 0 & 1 & 4 & & \\
\hline Time lag: & & & & & & & \\
\hline The first day & 1 & 4 & 0 & 2 & 3 & 0.33 & 0.92 \\
\hline The first week & 6 & 7 & 3 & 6 & 10 & & \\
\hline Level of fracture: & & & & & & & \\
\hline Proximal & 1 & 3 & 1 & & & 0.75 & \\
\hline Distal & 6 & 8 & 2 & & & & \\
\hline Time of union: & & & & & & & \\
\hline 〔 24 weeks & 7 & 5 & 1 & & & 0.04 & \\
\hline$>24$ weeks & 0 & 6 & 2 & & & & \\
\hline
\end{tabular}




\section{Discussion}

Malalignment is common while fixation diaphyseo-metaphyseal tibial fractures with interlocking nail. In the present study, 16 cases with fractures distal BBL and 5 cases with fracture proximal BBL were studied prospective and retrospective. All cases were united with good alignment except 2 cases $(9.5 \%)$ with malalignment. There was valgus malalignment ( 7 degrees) in distal tibia due to fracture comminution and incorrect placement of blocking screw and the other case, there was varus malalignment (10 degrees) and recurvatum (5 degrees) in proximal tibia due to fixation by conventional nail, blocking screw and loosening of single locking screw. Mean varus valgus malalignment was 0.81 degree while mean recurvatum and procurvatum malalignment was 0.23 degree. Krettek C \& coworkers [7] studied, prospectively, 21 tibial fractures, 10 in the proximal third and 11 in the distal third after the insertion of Poller screws over a mean period of 18.5 months (12 to 29). All fractures had united. Healing was evident radiologically at a mean of $5.4 \pm 2.1$ months (3 to 12 ) with a mean varus-valgus alignment of -1.0 degree ( -5 to 3$)$ and mean procurvatum-recurvatum alignment of 1.6 degrees ( -6 to 11 ). Seung Wook Yang, Hyung Taek Park and Kuen Tak Suh [11] found in their study with 31 cases with proximal and distal tibial fracture treated with interlocking intramedullary nailing that malalignment was found in 9 cases out of $31(29 \%)$. They found malalaignment in 7 cases (78\%) out of 11 in proximal fracture, 2 cases $(22 \%)$ out of 20 in distal fracture $(p<0.001)$. Parth et al. [15] found in their prospective study of treatment of diaphysio-metahpyseal tibial fractures with expert tibial nail that 7 cases of 30 cases developed malalignment.

In the present study, the design of interlocking nail was statistically significant wiith the final clincal result ( $p$-value $=0.04)$. Better results were with expert nail. Both Henley and coworkers [12] and Laflamme [13] demonstrated the problems associated with limited fixation in the proximal segment, and implant modifications to include additional oblique/multiplanar interlocking bolt options have minimized loss of fracture reduction. Venkatesh et al. [14] found in their Comparative Study of Functional Outcome Between Expert Tibial Nailing and Conventional IMIL Nailing for Proximal and Distal Tibial Fractures in Adults that 100 patients with proximal and distal tibial fractures who were fixed by conventionl ILN in 50 patients and by expert tibial nail in the other fifty. It was statistically insignificant with the time of union
( $p$-value $=0.138)$ similar to the present study but it was statistically insignificant with the final clinical result ( $p$-value $=0.827)$ in contrast to the present study in which ILN design was statistically significant with the final clincal results ( $p$-value $=0.04)$. Better results were in cases of fixation by Expert tibial nail.

In the present study, in this study, time of union was in less than 24 weeks in 13 cases $(62 \%)$ while the time was mre than 24 weeks in eight (38\%). Average time for union was 24 weeks. Six cases $(28.5 \%)$ were delayed in union and need dynamization and bone grafting in one. Excellent results were in cases with rapid union less than 24 weeks. Time of union was statistically significant with the clinical result. These results were slightly different from the study done by Parth et al. [15] who, found that 27 patients $(90 \%)$ united in $<20$ weeks, one (4\%) united betwwen 20-24 weeks and two (6\%) united in $>24$ weeks and fully united in 28 weeks. Their results are superior to the results in this study. This might be due to their use of expert tibial nail in all cases and the fracture typ difference.

Mode of trauma and AO type of fracture were statistically significant with time of union $(p$-value $=$ 0.01 and 0.001 respectively). Rapid union (in less than 24 weeks) was more in simple twisting trauma and simple fracture pattern. The results were similar to the results of the study done by Parth et al. [15] on diaphysio metaphyseal tibial fractures and found in their study that all patients with simple low velocity trauma and simple fracture have excellent results.

In the present study, smoking was statistically significant with the time of union ( $p$-value $=0.01$ ). Union was more rapid in nonsmoker than smoker. This was similar to the study done by Patel, et al. [16] who found that smoking has a negative effect on bone healing, in terms of delayed union, nonunion and more complications.

In the present study, fixation of fibula was statistically significant with the time of union ( $p$ value $=0.031$ ). This may be due to decreased cyclic compression at the fracture site. Fixation was done in 4 cases where there was affection of ankle stability as in 2 cases or residula malalignment after fixation with major translation and comminution. Mosheiff et al in his comparative study in $\mathbf{7 2}$ patients with unstable fracture distal BBL who were divided into two groups. 25 patients group was treated by ILN \& fibular fixation and 47 patients control group was treated by ILN only. 
He found that Cases were more likely to have the associated fibula fracture stabilized where the tibia fracture was very distal. Plating of the fibula fracture was significantly associated with maintenance of reduction and alignment 12 weeks or later after surgery $(p$-value $=0.036)$. Dogra et al., [17] reported that in 3 patients of the 15 of their series presented angle in varus or valgus $>5^{\circ}$, without fibular fixation. Schmidt et al., [18] reported that fibular fixation must be performed before fixating tibia with intramedullary nail when there is a major fibular deviation, because this helps on restoring the alignment of the limb or when there is gross tibial comminution. These two studies were different from the present study results, on the other hand Goldsztajn et al., [19] study treated 26 patients with intramedullary nail and found $88.5 \%$ of anatomical reduction of the tibia at early postoperative period, without requiring fibular fracture fixation which was similar to the present study.

\section{Conclusion:}

The use of blocking (poller) screws in combination with an intramedullary nail is an important additional option that can be used to improve reduction and fixation of long-bone fractures at the metaphysio-diaphyseal junction, where there is a strong tendency for axial displacement. In cases of fracture distal BBL, fibular fixation should be done if there is residual malalignment after fixation by ILN \& blocking screw or the fibular fracture is a part of ankle syndesmosis (within 8$10 \mathrm{~cm}$ of distal fibula). Better results are when the fixation is done by Expert tibial nail with multidrectional locking screws with better fixation and stability.

\section{Acknowledgements:}

This research was carried out without funding.

\section{Conflicts of interest:}

No conflicts of interest declared.

\section{Authors contributions:}

All authors had equal role in design, work, statistical analysis and manuscript writing. All authors have approved the final article work.

\section{References}

1- AHLERS J. and VON ISSENDORFF W.D.: [Incidence and causes of malalignment following tibial intramedullary nailing]. Feb., 18 (1): 31-6, 1992.

2- MEENA R.C., MEENA U.K., GUPTA G.L., GAHLOT N. and GABA S.: Intramedullary nailing versus proximal plating in the management of closed extra-articular prox- imal tibial fracture: A randomized controlled trial. J. Orthop. Traumatol. Sep., 16 (3): 203-8, 2015.

3- HAK D.J.: Intramedullary Nailing of Proximal Third Tibial Fractures: Techniques to Improve Reduction. Stahel PF, editor. Orthopedics Jul., 134 (7): 532-5, 2011.

4- HIESTERMAN T.G., SHAFIQ B.X. and COLE P.A.: Intramedullary nailing of extra-articular proximal tibia fractures. J. Am. Acad. Orthop. Surg. Nov., 19 (11): 690700, 2011.

5- WYSOCKI R.W., KAPOTAS J.S. and VIRKUS W.W.: Intramedullary Nailing of Proximal and Distal One-Third Tibial Shaft Fractures With Intraoperative Two-Pin External Fixation. J. Trauma. Inj. Infect. Crit. Care. Apr., 66 (4): 1135-9, 2009.

6- AZEVEDO FILHO F.A.S. De, COTIAS R.B., AZI M.L. and TEIXEIRA A.A. De A.: Reliability of the radiographic union scale in tibial fractures (RUST). [cited 2018 Apr. 8], 52 (1): 35-9, 2017.

7- KRETTEK C., STEPHAN C., SCHANDELMAIER P., RICHTER M., PAPE H.C. and MICLAU T.: The use of Poller screws as blocking screws in stabilising tibial fractures treated with small diameter intramedullary nails. J. Bone. Joint. Surg. Br. Nov., 81 (6): 963-8, 1999.

8- EHLINGER M., ADAM P., GABRION A., JEUNET L., DUJARDIN F., ASENCIO G., et al.: Distal quarter leg fractures fixation: The intramedullary nailing alone option. Orthop. Traumatol. Surg. Res. Oct., 96 (6): 674-82, 2010.

9- IM G.I. and TAE S.K.: Distal metaphyseal fractures of tibia: A prospective randomized trial of closed reduction and intramedullary nail versus open reduction and plate and screws fixation. J. Trauma. Nov., 59 (5): 1219-23, Discussion 1223, 2005.

10- NORK S.E., SCHWARTZ A.K., AGEL J., HOLT S.K., SCHRICK J.L. and WINQUIST R.A.: Intramedullary Nailing of Distal Metaphyseal Tibial Fractures. J. Bone. Jt. Surg. Jun., 187 (6): 1213, 2005.

11- YANG S.W., PARK H.T. and SUH K.T.: Malalignment of Tibial Fracture Following Interlocking Intramedullary Nailing. J. Korean. Soc. Fract., 13 (2): 236, 2000.

12-HENLEY M.B., MEIER M. and TENCER A.F.: Influences of some design parameters on the biomechanics of the unreamed tibial intramedullary nail. J. Orthop. Trauma., 7 (4): 311-9, 1993.

13- LAFLAMME G.Y., HEIMLICH D., STEPHEN D., KREDER H.J. and WHYNE C.M.: Proximal tibial fracture stability with intramedullary nail fixation using oblique interlocking screws. J. Orthop. Trauma. Aug., 17 (7): 496502, 2003.

14- VENKATESH S.K. GUPTA1, PRABHU B1 and VEER ABHISHEK GOUD2* DSS A.: Comparative study of functional outcome between expert tibial nailing and conventional IMIL nailing for proximal and distal tibial fractures in adultse. https://scientiaricerca.com/[Internet] 2 (1). Available from: https://scientiaricerca. com/srortr/ SRORTR-02-000042.php, 2018.

15- GAWATRE D.P., MORADIYA D.N., PATEL D.K. and DESAI DT V.: Proximal and distal metaphyseo-diaphyseal fractures of tibia in adults treated with tibia interlock nail with multiaxial locking (A Study of 30 Cases). Int. J. Orthop. Sci. Jan., 13 (1e): 308-13, 2017. 
16- PATEL R.A., WILSON R.F., PATEL P.A. and PALMER R.M.: The effect of smoking on bone healing: A systematic review. Bone. Joint. Res., 2 (6):102-11, 2013.

17- VARSALONA R. and LIU G.T.: Distal tibial metaphyseal fractures: The role of fibular fixation. Strateg Trauma Limb Reconstr Dec., 141 (1): 42-50, 2006.
18- GAWALI S.R., KUKALE S.B. and NIRVANE P.V.T.R.: Management of Fractures of Distal third Tibia by Interlock Nailing. J. Foot. Ankle. Surg., 3 (1): 15-22, 2016.

19- SOCIEDADE BRASILEIRA De ORTOPEDIA E. TRAUMATOLOGIA: Regional de Sa o Paulo. Acta ortopédica brasileira. Sociedade Brasileira de Ortopedia e Traumatologia (SBOT) Regional de Sa o Paulo.

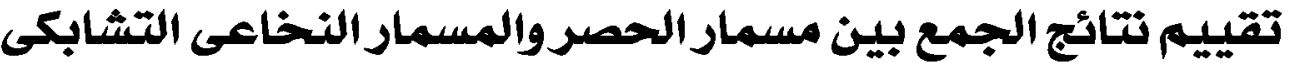

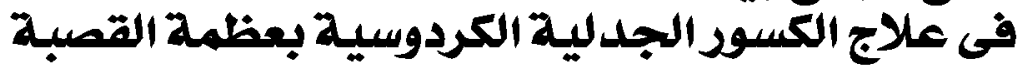

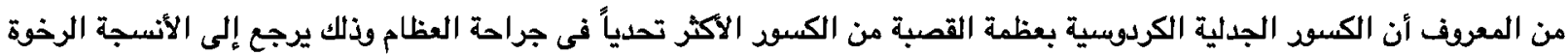

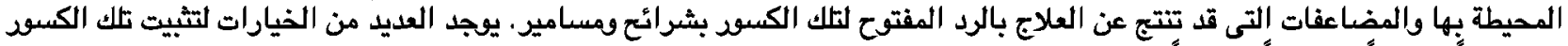
أما علاجاً تحفظياً أو علاجاً جراحياً.

يتم اللجوء للعلاج التحفظى بواسطة جبس فوق الركبة فى حالة الكسود الثابتة الغير متزحزحة، وهذا النوع من العلاج غير ملائم لعلاج الكسود الغير مستقرة والمتزحزحة وبها عدم أستقامة لعظمة القصبة.

يتم اللجوء للعلاج التحفظى بواسطة جبس فوق الركبة فى حالة الكسود الثابتة الغير متزحزحة، وهذا النوع من العلاج غير ملإئمائم لعلاج

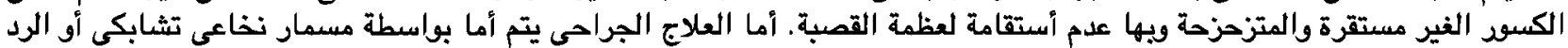

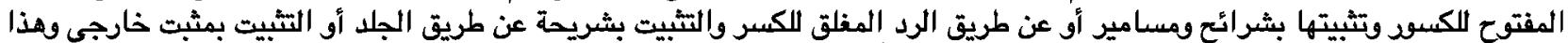

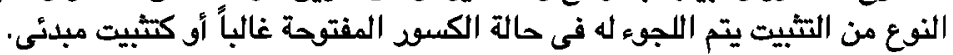

تظهر عيوب الرد المفتوح للكسر فى أحتمالية تهتك الأنسجة الرخوة والألتهابات المزمنة بالعظام وعدم ألتئام الكسر. وبناءاً على ما سبق فإن العلاج بتشييت هذه الكسود بمسمار نخاعى تشابكى أو الرد المغلق للكسر والتثبيت بشرائح ومسامير عن طريق الجلد، يعتبر من أكثر الطرق أماناً ونتائج جيدة.

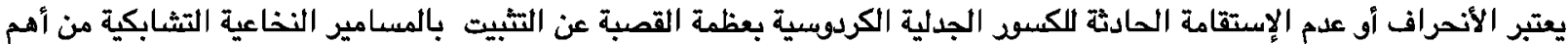

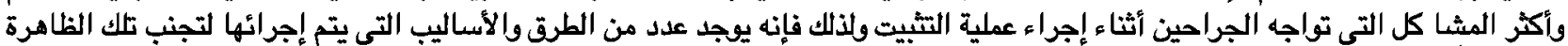

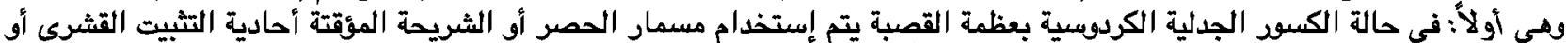

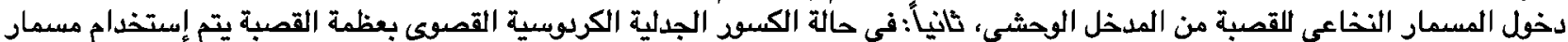
الحصر أو الثريحة المؤقتة أحادية الثبيت القشرى أو تشييت عظمة الشظية كى تمثل دعامة لعظمة القصبة لمنع الإنحراف.

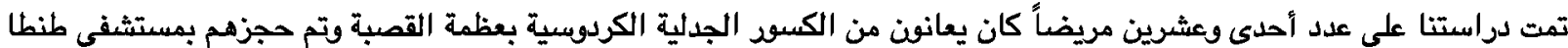

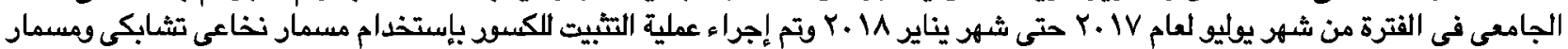
الحصر لتجنب ظاهرة الإنحراف التى قد تحدث.

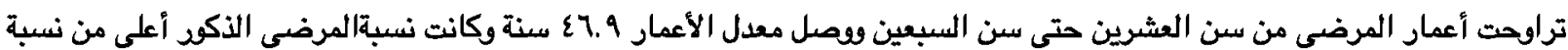

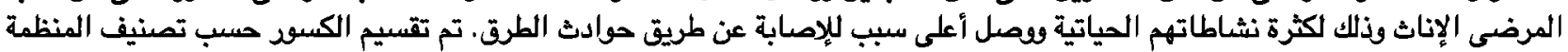
العالمية اللكسو وتم تصنيف الأنسجة الرخوة حسب تصنيف تيشرن لتقيبم حالة الأنسجة الرخوة بعد الإصعابة.

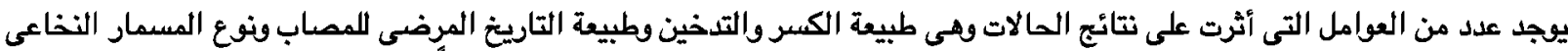
التى تم إستخدامه والدقة فى تركيب المسمار النخاعى وبداية ويداية حركة مفصلى الركبة والكاحل مبكراً بعر العملية مباشرة.

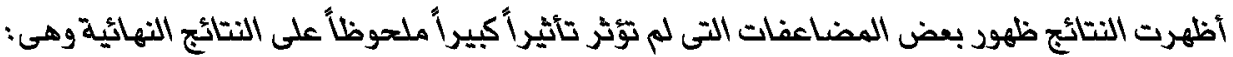

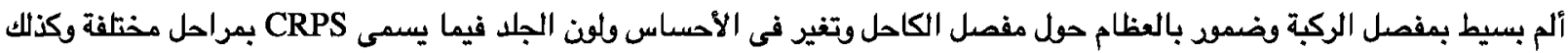

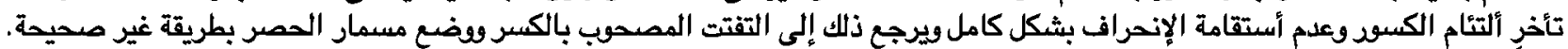

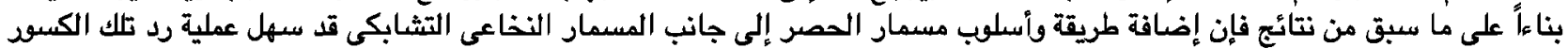

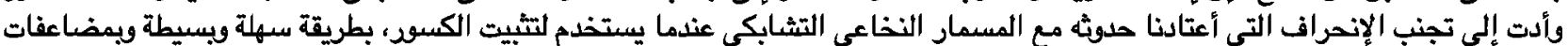

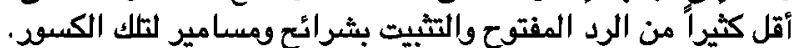

